\title{
DEVELOPMENT OF ICT: CONCEPTUAL COMPARATIVE ANALYSIS OF CONSUMER BEHAVIOR IN EUROPE AND ASIA
}

\author{
Khaled AL MAJZOUB ${ }^{1}$, Vida DAVIDAVIČIENE் ${ }^{2 *}$ \\ Department of Business Technologies and Entrepreneurship, Faculty of Business Management, \\ Vilnius Gediminas Technical University, Saulètekio al. 11, LT-10223, Vilnius, Lithuania \\ *E-mail: vida.davidaviciene@vgtu.lt
}

\begin{abstract}
Today's society is becoming the information and communication technology societies, where ICT is responsible for the creation, distribution, and manipulation of information in every aspect of society (Xiang, Magnini, \& Fesenmaier, 2015). The following article will present a comparative analysis of one aspect of consumer changes caused by ICT, which is e-commerce between Europe and Asia, using Hofstede's culture dimensions (Power distance, individualism, masculinity and uncertainty avoidance).
\end{abstract}

Purpose - to provide a comparative analysis of consumer behavior changes caused by ICT between Europe and Asia. Research methodology - a synthesis of review of the literature.

Findings - provide insight into the difference in consumer behavior changes caused by ICT, between Europe and Asia and provide the basis for future researches.

Research limitations - future research should include empirical research and study of other solution and other factors that affect consumer behavior.

Practical implications - the practical implication of the article provide a framework for organizations to take into consideration, the difference in consumer behavior between countries when it is targeting their markets.

Originality/Value - no comparative.

Keywords: information and communication technologies, organizational behaviors, consumer behavior, culture change, digitalization.

JEL Classification: M10, M150.

Conference topic: Digitalization of Business Processes: Trends, Challenges, Solutions.

\section{Introduction}

The rapid development of ICT generated a series of changes in dynamics and structures for all industries (Fortuna \& Mihaela, 2016). Today's society is becoming the information and communication technology societies, where ICT is responsible for the creation, distribution and manipulation of information's in every aspect of society. Whether it is social, economic or cultural. It is creating a change in mentality which results in changing human behavior (Belletich \& Villarreal, 2017). ICT affects all aspects of human society such as health, education, and economics. It is possibilities has no limits. ICT lead to an increase in a number of markets, great transparency of information, reduce operation cost and provide lower cost (Mihajlović, Krželj, \& Milić, 2014). Internet technology benefited countries by delivering economic values, which improves people's lives (Ooi, Sim, Yew, \& Lin, 2011). The adoption of the internet provided the basis for the development of new systems that links consumers, which lowered the barrier entry to new players (Xiang, Wang, O'Leary, \& Fesenmaier, 2015). The internet is the most popular communication channel. Peoples time spend on the internet increased significantly, which promotes the advertiser to allocate part of the budget for online adverting. The benefit of online advertising its reach content, interactivity, accurate targeting and lower cost (Liu, Lo, Hsieh, \& Hwang, 2018). Information and communication technology are becoming an essential part of people's life. The advanced development of the internet of things (IoT) and digitalization made ICT usable everywhere and increased its dependency on our daily activities (Pihkola, Hongisto, Apilo, \& Lasanen, 2018). The introduction of information and communication technology has transformed the traditional commerce (Ballestar, Grau-Carles, \& Sainz, 2016). The growth and access of the internet have changed and shifted the use of information-oriented industries such as online 
shopping, banks, tourism, and security trading services. Which lead to an increase in e-commerce of these industries (Wang, Cho, \& Denton, 2017). ICT has a direct and indirect effect on the environment that use it. Direct effects include resources, disposal of Hardware and emission used by production. Indirect effects include changing in the pattern for both consumers and producers (Bieser \& Hilty, 2018) ICT facilitates the coordination between sellers and buyers, which will result in increased access to global supply chain (Mihajlović, 2014). Countries with less ICT may grow less (Robertson, 2015). Although a lot of researches were done on the effect of ICT on consumer behavior, there is no comparative analysis done on e-commerce consumer behaviors changes caused by ICT between Europe and Asia.

The purpose of the article is to provide comparative analysis on e-commerce consumer behavior changes caused by ICT between Europe and Asia.

To reach the goal the following tasks were addressed:

- to make an analysis of recent scientific works in e-commerce and consumer behavior;

- to perform comparative analysis on Consumer behavior in e-commerce between Europe and Asian.

For reaching the goal such methods as comparative literature analysis, synthesis, statistical data analysis, and comparison were employed.

\section{Review of literature}

\subsection{E-commerce concept}

E-Commerce is becoming an indispensable part of modern life. The volume of data generated from e-commerce provides a big data warehouse that can be analyzed and better understand consumers behavior. Especially data from consumers review about products and service they purchased which reveals their sentiment about what they consumed, which provide valuable information for management to enhance their decision making (Yuan, Xu, Li, \& Lau, 2018). In the last two decades due to the rapid development of ICT, various types of $\mathrm{B} 2 \mathrm{C}$ model are leveraging technology to enhance their market position and gain competitive advantages over their competitors. Moreover, new technologies like smartphones, IoT, artificial intelligence and deep learning are expected to reform consumers purchasing behaviors. Thus, Online channel will be a dominant force in the retail industry. Mobile devices are the leading type of promotional tools that use personalized promotion, using social media and location-based promotions (Park \& Kim, 2018). Social media communities influence consumers' product attitudes and purchasing design, which includes adoption and use of the product or service, brand trust, and brand loyalty. Companies use social media to influence community member opinion and purchase intentions. In social media communities, a huge number of members participate in online conversations that will lead to the generation of online content. Social influence is defined as "the concept of people modifying their behavior to bring them closer to the behavior of their friends". Social influence occurs when an individual behavior is influenced by the people surrounding him. There are two types of influence:

- normative where the person conforms to group norms;

- informational when the individual search for information from knowledgeable peers or observe peer behavior (Y. Chen, H. Chen, \& Xu, 2016).

Another model of e-commerce is consumer-to-consumer (C2C) which allow consumers to electronically buy and sell directly from each other. $\mathrm{C} 2 \mathrm{C}$ is exerting pressure on the traditional retailing. The advancement of ICT allowed the developer of many platforms that support $\mathrm{C} 2 \mathrm{C}$, which include more variety of products and services at lower prices. Also, Consumers can make the purchase anytime they want from anywhere. Companies are trying to build platforms that support $\mathrm{C} 2 \mathrm{C}$ to gain more understanding of their consumer's behavior, especially the consumers that use social media, since customer value is the key concept in marketing and retailing (Saarijärvi, Joensuu, Rintamaki, \& Yrjölä, 2018).

One of the most important factors to use and adopt e-commerce is trust. Researchers in information and communication technology found that customer loyalty is directly affected by the ability of customers to personalization their services or products according to their preferences (Wang et al., 2017). Electronic commerce allowed companies to sell their products and services without the need for brick-and-mortar stores. E-commerce is becoming a regular way to do business, building social trust will improve the growth of the economy. E-commerce is very important for small and mid-sized companies, it will give a competitive edge over big corporation, as it provides quick responses to the emerging trends in purchased products (Bucko \& Ferencová, 2018). The number of retailers that use multiple channels to sell their products or service is growing. At the same time, consumers are exposed to multiple channels to choose from where to do their purchase. Consumers sometimes search for a product in channel X in Company A, but they end buying it from channel Y in company B. Consumers sometime may use "Showrooming" to make the purchase. Showrooming occurs when consumers visit the store to have information or conduct research about the product and then order it online for a various reason. For example, product cost online is cheaper than in-store (Dony, Heejae, \& Sotaro, 2018). Social network servicing has changed the concept of e-commerce by integrating the social aspects with the commercial functionalities that created C2C (Consumer to Consumer) social commerce. Providing people with functionality to generate extra income by providing services that allow them to sell second hand and other products, by posting them on social networks like Facebook, line, and webchat (Sukrat, Mahatanankoon, \& Papasratorn, 2018). 
The social network allows organizations to reach their target audience by providing appropriate marketing and communication tools, it also enables the establishment of a relationship with customers (Raudeliuniene, Davidavičiene, Tvaronavičiene, \& Jonuška, 2018).

Online shopping refers to electronic commerce which is selling and buying products and services directly from the seller on the internet. Customers attitudes to make a purchase online is decided by two factors trust and the perceived benefits. Asia Pacific region is leading the growth of online shopping compared to other regions (Rahman et al., 2018). Consumer spending is a key indicator of economic activity. In recent years there is a dramatic shift toward online purchasing. Online shopping has witnessed explosive growth in the last decade compared to traditional shopping, due to the development and advance in information and communication technology. In the beginning, people were afraid to use online shopping to varies reason, some of them are online fraud, the leak of personal information, delay in shipment, inconsistency between what is offered online and what is delivered. But, these concerns today are at a lower level due to the awareness of people about what online shopping could offers. Online shopping has multiple advantages, some of are, buy anytime anywhere, provide consumers with more information and opportunities to compare products, buy the same product at a lower price, avoid a traffic jam, eliminate the pressure when communicating face-to-face (Vasic et al., 2019). Online shopping uses software that gathers information about customers performances and provides customized suggestions (Acai, Sonnadara, \& O'Neill, 2018). One of the factors that lead to a delay in the decision to make the purchase is the difference between technology improvement and expectations of consumers. Consumers make a purchase based on expected benefits that they will receive or based on the value the product will create. If the improvement of the current product is not expected to appear in the near future, then the cost and benefits will be the main deciding factors to make the purchase. However, if a new development for the product is expected to come soon, there will be a delay in the purchase decision (Ha, 2018). The advancement of ICT has changed the way on how goods and services are bought and sold. Today most users prefer not only to shop online but also to purchase abroad taking advantage of cross-border e-shopping. Online shopping allows customers to buy anything from anywhere at any time. E-shopping allow for wider access and variety of products with less cost and less costly communication (Saprikis, 2015). It is important to understand the potential benefits that new technologies will provide, better engagement with customers and meet their expected demands. Companies are searching for many channels on how to communicate with customers at every stage from the buying process to post-consumer process (Marino et al., 2018). The effort required to keep a customer is much less than to obtain a new customer, that why companies are extending the ways to find how to expand customers usage of online shopping sites (Ijaz, 2018).

One of the popular trends in online shopping with the rapid growth of ICT is smart mobile phones. M-commerce or m-shopping refer to using mobile for purchasing online. M-commerce is growing at $39 \%$ each year and it is estimated to exceed $\$ 31$ billion dollars. $80 \%$ of global consumers are owning mobile phones, which took the attention of marketers to understand the consumer's mobile preference to provide personalized products and services to consumers (Saprikis et al., 2018).

For organizations to gain competitive advantage, it must offer products and services that will meet their customers demand and provide added value, organizations must communicate with their customers and meet their needs by offering personalized products and services. To obtain this, organizations must give priority to e-commerce, because it provides their customers with the ability to shop online, post feedback and to communicate their needs. Hence, the organization communicates with its customers they can know and predict their consumer behaviors.

\subsection{Consumer behavior}

Knowledge of customer behaviors and their preference is vital for competition and survival of organizations. Knowing what customers want whether it is service, or products provide companies with an edge over their competitors, and the product or service released will be wanted by the customers. The modern marketing is customer oriented, which requires organizations to acquire as much as data about their customers and their preferences. Which will enable them to send personalized messages to them, taking into accounts their needs, capabilities, and interest of individual target groups (Lipowski \& Angowski, 2017)? Since customer satisfaction will lead to customer return, which will result in high expected cash flow, which will allow the companies to grow (Vo et al., 2016). Companies are searching for new ways to compete in the markets and satisfy customer demands and increase sales. Companies are using a lot of technology from sensors, logs, and mechanical systems to store, retrieve and analyze the data to better understand their customer's behavior, and act quickly to identify new opportunities and innovate (Scherer, Kloeckner, Ribeiro, Pezzotta \& Pirola, 2016). Internet of things (IoT) is changing consumers behavior. Consumers are facing a lot of challenges dealing with all kind of buying and consuming goods or services which is caused by digitalization. Physical and digital worlds are merged together which allow people to procure products and services. Whether these products or services in health, finance, banking, housing, education or leisure. This penetration of the Internet caused a change in consumer behaviors. For example, Products information not printed on products anymore, it is available online. Payment systems like debit and card cards are replacing cash payments (Stevens, Bossauer, Neifer, \& Hanschke, 2018). Companies used the data collected from IoT to track consumer behaviors and create personalized products and services. IoT provides a company with a lot of data collected about customers preferences, lifestyle, habits, and behaviors. IoT is shifting consumers behaviors form late adopters to early adopters (Caputo, Scuotto, Carayannis, \& Cillo, 2018). It is very critical 
for organizations to understand the impact of ICT on consumer behaviors and develop effective marketing strategies. It is important to understand the effect of these technologies with the potential to serve their long term strategies (Xiang et al., 2015). Among and the most important factor that affects consumer behavior is culture (Ijaz, 2018). The effect of culture on consumer behavior is becoming interesting in recent years. Hofstede dimensional model of national culture is mostly used in the researches, although it is produced in early of the 1970s, many replications of Hofstede model proved it is still valid (de Mooij \& Hofstede, 2011). There are some purchasing behaviors that are common to consumers regardless of their culture, however, there exist some purchases that highly culture specific (Nieves-Rodriguez, Perez-Rivera, Longobardi, \& Davis-Pellot, 2017). Culture is critical for the success or failure of organizations. Management success practice in one culture do not necessary means success in another culture (Rajh, Budak, \& Anić, 2016). Hofstede is the leading research in examining the cross-culture difference. Culture is defined as "a stable and dominant cultural character of a society shared by most of its individuals and remaining constant over long periods of time". In studying culture, Hofstede defined four core culture dimensions: power distance, uncertainty avoidance, individualism-collectivism \& masculinity-femininity (Jahandideh, Golmohammadi, Meng, O'Gorman, \& Taheri, 2014). In Table 1 these dimensions are presented taking in mind research results presented by Mooij and Hofstede 2011; Jahandideh et al., 2014; Rajh et al., 2016; Zhang, Weng, and Zhu, 2018; Xie and Pai, 2018; Kübler, Pauwels, Yildirim, and Fandrich, 2018; Su, Min, Chen, and Swanger, 2018; Lu et al., 2018.

Table 1. Hofstede four core culture dimensions (source: compiled by the authors Mooij \& Hofstede, 2011; Jahandideh et al., 2014; Rajh et al., 2016; Zhang, Weng, \& Zhu, 2018; Xie \& Paik, 2018; Kübler et al., 2018; Su et al., 2018; Lu et al., 2018)

\begin{tabular}{|c|c|c|c|c|c|c|c|}
\hline \multicolumn{2}{|c|}{ Power Distance } & \multicolumn{2}{|c|}{ Individualism } & \multicolumn{2}{|c|}{ Uncertainty Avoidance } & \multicolumn{2}{|c|}{ Masculinity } \\
\hline High & Low & High & Low & High & Low & High & Low \\
\hline $\begin{array}{l}\text { purchas- } \\
\text { ing } \\
\text { brands } \\
\text { with Sta- } \\
\text { tus }\end{array}$ & $\begin{array}{l}\text { more easily } \\
\text { open to adopt } \\
\text { and use new } \\
\text { technologies }\end{array}$ & $\begin{array}{l}\text { standardized } \\
\text { products; } \\
\text { focus on the } \\
\text { characteristics } \\
\text { of the new } \\
\text { technology } \\
\text { and e-com- } \\
\text { merce rather } \\
\text { than on word- } \\
\text { of-mouth }\end{array}$ & $\begin{array}{l}\text { customized } \\
\text { products; } \\
\text { prefer the } \\
\text { word-of- } \\
\text { mouth to } \\
\text { adopt or use } \\
\text { new technol- } \\
\text { ogy or e-com- } \\
\text { merce }\end{array}$ & $\begin{array}{l}\text { spend on } \\
\text { clothes and } \\
\text { footwear to } \\
\text { reduce their } \\
\text { social risk and } \\
\text { spend on } \\
\text { medical and } \\
\text { health care to } \\
\text { reduce their } \\
\text { physical risk. }\end{array}$ & $\begin{array}{l}\text { spend more } \\
\text { on fitness } \\
\text { and sports }\end{array}$ & $\begin{array}{l}\text { Status } \\
\text { brands and } \\
\text { jewelry are } \\
\text { important to } \\
\text { show one's } \\
\text { success }\end{array}$ & $\begin{array}{l}\text { purse sta- } \\
\text { bility and } \\
\text { comfort } \\
\text { of life }\end{array}$ \\
\hline
\end{tabular}

Four Hosted's dimensions are investigated by scholars and main points, which must be considered are:

- Power distance refers to the degree to which people in society accepts that power is distributed unequally (Rajh et al., 2016). Countries with high power distance show respect for the authority which may affect their decision making. Although they prefer to be told what to do, and they get influenced by the opinions of the people around them before adopting new technologies. Social influence has a huge influence on consumer behavior. Which implies that trust is a key point when targeting high power distance countries and it is a key indicator for using and adopting e-commerce. In high Power distance culture, the ones' social status is very important, so purchasing brands serve this purpose (de Mooij \& Hofstede, 2011). While in low power distance countries people are more easily open to adopt and use new technologies (Zhang, Weng, \& Zhu, 2018).

- Individualism culture assumes that their values are valid for the whole world. In individualism culture standardizing is very important (de Mooij \& Hofstede, 2011). Individualism and collectivism reflect the degree to which people prefer to take care of themselves and their families. In individualism countries, people make the decision independently and they also focus on the characteristics of the new technology and e-commerce rather than on word-of-mouth. While in collectivism people are depend on decision making and they prefer the word-of-mouth to adopt or use new technology or e-commerce (Zhang et al., 2018). In individualism countries product or service quality, prices and rates play a critical role in driving consumer decision making to make the purchase. While in collectivism culture people will seek their information from social network and group of people around them due to their strong herd preference. They put a lot of consideration on the views and rating of the early adopters of the new products and services (Zhang et al., 2018). Building relation is very important in collectivism culture (Xie \& Paik, 2018). Consumers in collectivism culture give more weight for the opinion of others before making a purchase decision. So, they are more sensitive to online rating provided for products or services. Where in individualism culture they prefer to "go their own way". Rating valence is higher in individualism cultures whereas rating volumes sensitivity is higher in power distance and uncertainty avoidance culture. Price sensitivity is higher in countries with high masculinity and uncertainty avoidance (Kübler, Pauwels, Yildirim, \& Fandrich, 2018). Individualism value pleasure seeking and independence, wherein collectivism they are 
related and attached to groups, sharing and collective identity. That's why it is important in collectivism culture to share gifts, while it is rare in individualism cultures (Su, Min, Chen, \& Swanger, 2018).

- Masculinity-femininity refers to the gender role differentiation inside society. masculine societies emphasize on material recognition, accomplishments, and achievement, while in feminine cultures value quality of life, which emphasizes human relationships and values friendship (Lu, Pattnaik, Xiao, \& Voola, 2018). In masculine society, achievement and success are very important and they must be demonstrated. Status brands and jewelry are important to show one's success (de Mooij \& Hofstede, 2011). In high masculine countries, perceived usefulness play an important role in adopting and using new technologies. While in feminine culture ease of use is an important indicator for using and adopting new technologies, where people purse stability and comfort of life (Xie \& Paik, 2018). High masculinity society is positively related to possession of luxury goods such as jewelry, suits, and watches, as people in high masculinity society need of signaling their social status (Su et al., 2018).

- Members of high uncertainty avoidance culture prefer the clarity for product-related categories. While low uncertainty avoidance culture has an active attitude towards life and plays more active sports (de Mooij \& Hofstede, 2011). Uncertainty avoidance dimension refers to the degree of ambiguous or uncertainty situation in societies that can be tolerated (Lu et al., 2018). People from high uncertainty avoidance (HUA) will value security more than people on low uncertainty avoidance culture. People from HUA Will be concerned about risks such as hacking, fraud and privacy issues (Xie \& Paik, 2018). In high uncertainty avoidance society, people prefer to buy known brands and follow widely accepted norms and reference groups to reduce the potential risks. They tend to spend on clothes and footwear to reduce their social risk and spend on medical and health care to reduce their physical risk. While people in low uncertainty avoidance adopt more active health approach and spend more on fitness and sports (Su et al., 2018). People from high uncertainty avoidance culture are resistant to change and less likely to take risks (Jahandideh et al., 2014).

Understanding culture is very important to be able to communicate e-commerce correctly. One model for identifying the culture difference is Hofstede's culture dimension. Hofstede provided a dimension that allow the organization to rank countries and based on the ranking they will implement their marketing strategies. Since there are products and services that are highly related and dependent on culture.

\section{Research methodology and results}

The research used in this article is a comparative analysis of synthesis of review of the literature on e-commerce consumer behavior changes, that were retrieved from seven databases (Web of Science, Emerald, ScienceDirect, Wiley, Taylor and Francis, Sage and Google Scholar) indexing scholarly journals on Hofstede and consumer change research.

Second, a statistical data analysis was processed. Comparative analysis was done on the population penetration in the two continents, in Europe, the level of penetration is $85.2 \%$ which is high compared to the percentage of penetration in Asia which is $49 \%$. The percentage of people shopping online in Europe is $69 \%$, while in Asia only $35 \%$. Although only $35 \%$ in Asia shop online, the number of customers buying online is higher than Europe, since Asia constitute $55.1 \%$ of world population, while Europe $10 \%$ as presented in Table 2 below.

Table 2. Internet, Facebook and Population Stats for Europe and Asia (source: Internet World Stats, 2018)

\begin{tabular}{|l|c|c|c|c|c|c|c|c|}
\hline Continent & $\begin{array}{l}\text { Population } \\
(\end{array}$ & & & & & & & \\
\hline Europe & $827,650,849$ & $10 \%$ & $704,833,752$ & $85.2 \%$ & $16.9 \%$ & $340,891,620$ & $69 \%$ & $6 \%$ \\
\hline Asia & $4,207,588,157$ & $55.1 \%$ & $2,062,197,366$ & $49.0 \%$ & $49.0 \%$ & $818,934,000$ & $35 \%$ & $9.4 \%$ \\
\hline
\end{tabular}

Further comparative analysis is on total revenue from online sales transaction and the percentage that each constitutes. Even the people shopping online in Asia constitute $35 \%$ of Asia total population, the revenues generated from Asia is $43.22 \%$ of the total worldwide revenue (as shown in below Table 3). Europe accounted for $23.81 \%$ of the total revenues generated worldwide although the percentage of people shopping online in Europe are $69 \%$ of the total population of Europe, which is almost double the percentage in Asia. Although there is a huge difference in sales and people who purchase online in both continents, the top two purchased categories products are same which are fashion, electronic and media (as shown in Table 4). This similarity will give companies the edge to expand their business and to capture online customers from both Europe and Asia, since online shopping is not bounded by space, especially in most sell online shopping categories (as shown in Table 4). Companies must follow the optimal strategies in targeting both markets in what they offer for their customers, that adhere to the norm and culture. 
Table 3. Revenue from online sales (source: Duncan, 2017)

\begin{tabular}{|c|c|c|c|}
\hline & Worldwide & Europe & Asia \\
\hline Revenue from Online Sales & $\$ 1.18$ Trillion & $\$ 28.1$ Billion & \$51 Billion \\
\hline$\%$ of Sales Revenue & $100 \%$ & $23.81 \%$ & $43.22 \%$ \\
\hline
\end{tabular}

Table 4. Top online category Products purchase (source: shop world, 2017; PostNord, 2018)

\begin{tabular}{|c|c|c|}
\hline$\#$ & Europe & Asia \\
\hline 1 & Fashion & Fashion \\
\hline 2 & Electronics and Media & Electronics and media \\
\hline 3 & Cosmetics, skincare, and haircare & Food \& personal care \\
\hline 4 & Home furnishings & Furniture and appliances \\
\hline 5 & Sport and leisure products & Health Supplements \\
\hline
\end{tabular}

The last comparative analysis was done on Consumer behavior using Hofstede four core dimensions between Europe and Asian Consumers and it is summarized in Table 5.

Table 5. Hofstede core dimensions comparison (source: compiled from authors below)

\begin{tabular}{|l|l|l|}
\hline \multicolumn{1}{|c|}{ Hofstede core dimensions } & \multicolumn{1}{|c|}{ Europe } & \multicolumn{1}{c|}{ Asia } \\
\hline \multicolumn{1}{|c|}{ Individualism/collectivism } & \multicolumn{1}{|c|}{ Europeans countries are individualism } & \multicolumn{1}{c|}{ Asian countries are collectivism } \\
\hline Power distance & Lower power distance than Asian Countries & score higher on power distance \\
\hline Uncertainty avoidance & $\begin{array}{l}\text { uncertainty avoidance Lower Compared to } \\
\text { Asian Countries }\end{array}$ & $\begin{array}{l}\text { a higher level of uncertainty avoidance } \\
\text { compared to European countries }\end{array}$ \\
\hline Masculinity/ femininity & Femininity & Masculinity \\
\hline Complain & Actively engaged in complaints & $\begin{array}{l}\text { Less likely to engage in Complaints. } \\
\text { They fear of losing face }\end{array}$ \\
\hline Creativity & $\begin{array}{l}\text { Score more on Creativity compared to Asian } \\
\text { countries }\end{array}$ & Weaker than European Countries \\
\hline
\end{tabular}

After comparing consumer behavior in e-commerce between Europe and Asia such main issues, which should be emphasized where identified:

- Asian countries are collectivism, while Europeans countries are individualism. Scholars assumed that individualism encourages divergent thinking and uniqueness which generate innovation and creativity. While in collectivism consensus and harmony among individual may hinder the creation of new creative ideas (Xie \& Paik, 2018).

- Asian countries score higher on power distance than European countries (Xie \& Paik, 2018). Asian consumers spend more on shopping luxury good than European consumers. Feeling powerless is one of the most important drivers for shopping for conspicuous products. In high power distance culture possessing visible and tangible products is used to boost the sense of power ( $\mathrm{Su}$ et al., 2018). Asian Countries are weaker in creativity compared to European since they score higher on the power distance index (Xie \& Paik, 2018).

- Asian countries have a higher level of uncertainty avoidance compared to European countries (Xie \& Paik, 2018).

- Asian consumers are less likely to complain compared to westerns. They fear of losing face. Instead, they engage in passive complaining actions such as negative word-of-mouth (Jahandideh et al., 2014).

As mentioned above, culture plays a significant role in influencing purchases, but there are other variables that can moderate this influence. Some studies used Gender (Nieves-Rodriguez et al., 2017), other used education (Rajh et al., 2016) as moderators influencing consumer purchase behavior. However, none of these studies are used to compare the difference in consumer purchasing behavior between Europe and Asia. The following hypothesis is proposed for future research to test the difference in consumer purchasing behaviors between Europe and Asia, including Gender and Education as influencing moderators. 


\section{Conclusions}

ICT has caused a change in consumer behavior, which introduced a new type of commerce called e-commerce. An increasing body of knowledge is available that helps explain differences in consumer behavior across culture and how it shapes consumer behaviors. Existing researches focused only on studying specific countries and no comparative Analysis was done to compare the difference and similarities between different regions in the world. Organizations must study and analyze this change in behavior to meet its customer expectation, and to gain a competitive advantage over it is competitors. One of the most factor to study for organizations success is culture. Hofstede dimensional model is one of the best models for understanding the factors that are affected by the culture which are power distance, Individualism/ collectivism, uncertainty avoidance, and Masculinity/ femininity. European countries are individualism and Feminine societies, whereas Asian countries are collectivism and Masculine societies. European countries are Lower in power distance and uncertainty avoidance than Asian countries. Understanding these factors will help organizations to gain a better understanding of society and to develop an optimal strategy that will provide business success. Applying this understanding will provide companies with effectiveness in applying effective strategies within and across global markets.

The limitation of this research is only concentrating on one solution which is e-shopping and one factor which affect consumer behavior, which is culture. Future research should include empirical research and study of other solution like e-banking and other factors that affect consumer behavior. Future research should concentrate more on moderating factors along with culture to have more accurate results. The study should also, split Europe and Asia into multiple regions and examining the different across them. For example, in Europe, the difference between west and east Europe should be studied, in Asia, southwest Asia, and the middle east.

\section{Disclosure statement}

We declare that we do not have any competing financial, professional, or personal interests from other parties.

\section{References}

Acai, A., Sonnadara, R. R., \& O’Neill, T. A. (2018). Getting with the times: a narrative review of the literature on group decision making in virtual environments and implications for promotions committees. Perspectives on Medical Education, 7(3), 147155. https://doi.org/10.1007/s40037-018-0434-9

Ballestar, M. T., Grau-Carles, P., \& Sainz, J. (2016). Consumer behavior on cashback websites: Network strategies. Journal of Business Research, 69(6), 2101-2107. https://doi.org/10.1016/j.jbusres.2015.12.015

Belletich, O., \& Villarreal, M. P. de. (2017). Knowledge of the natural and social environment in ICT consumer children. Procedia - Social and Behavioral Sciences, 237(June 2016), 164-168. https://doi.org/10.1016/j.sbspro.2017.02.058

Bieser, J. C. T., \& Hilty, L. M. (2018). Assessing the indirect environmental effects of information and communication technology (ICT): A systematic literature review. Sustainability (Switzerland), 10(8), 1-19. https://doi.org/10.3390/su10082662

Bucko, J., \& Ferencová, M. (2018). Online shopping: Factors that affect consumer purchasing behavior. Cogent Business \& Management, 5, 1-15. Retrieved from https://doi.org/10.1080/23311975.2018.1535751

Caputo, F., Scuotto, V., Carayannis, E., \& Cillo, V. (2018). Intertwining the internet of things and consumers' behavior science: Future promises for businesses. Technological Forecasting and Social Change, 136, 277-284. https://doi.org/10.1016/j.techfore.2018.03.019

Chen, Y., Chen, H., \& Xu, L. (2016). Social media and eBusiness: cultural impacts on the influence process in consumer communities. IOP Conference Series: Materials Science and Engineering, 142, 1-10. https://doi.org/10.1088/1757$899 \mathrm{X} / 142 / 1 / 012134$

de Mooij, M., \& Hofstede, G. (2011). Cross-cultural consumer behavior: A review of research findings. Journal of International Consumer Marketing, 23(3-4), 181-192.

Dony, W., Heejae, D., \& Sotaro, S. (2018). On whether and how much consumers engage. Electronic Commerce Research, 18(4), 665-692. https://doi.org/10.1007/s10660-017-9277-4

Duncan, E. (2017). Online shopping in Europe - statistics \& amp; facts | Statista. Retrieved from https://www.statista.com/topics/ 3881/online-shopping-in-europe/

Fortuna, A., \& Mihaela, A. (2016). The influence of new technologies on tourism consumption behavior of the millennials. Amfiteatru Economic, 18(Special Issue 10), 829-829. Retrieved from https://ideas.repec.org/a/aes/amfeco/vs10y2016i18p829.html

Ha Y. (2018). Expectations gap, anticipated regret, and behavior intention in the context of rapid technology evolvement, Industrial Management and Data Systems, 118(3), 606-617. https://doi.org/10.1108/IMDS-02-2017-0045.

Ijaz, M. F. (2018). Constituents and consequences of online-shopping in sustainable e-business: an experimental study of onlineshopping malls. Sustainability, 10(10), 1-24. https://doi.org/10.3390/su10103756

Internet World Stats. (2018). Europe internet usage stats Facebook subscribers and population statistics. Retrieved from https://www.internetworldstats.com/stats4.htm 
Jahandideh, B., Golmohammadi, A., Meng, F., O'Gorman, K. D., \& Taheri, B. (2014). Cross-cultural comparison of Chinese and Arab consumer complaint behavior in the hotel context. International Journal of Hospitality Management, 41, 67-75. https://doi.org/10.1016/j.ijhm.2014.04.011

Kübler, R., Pauwels, K., Yildirim, G., \& Fandrich, T. (2018). App popularity: where in the world are consumers most sensitive to price and user ratings? Journal of Marketing, 82(5), 20-44. https://doi.org/10.1509/jm.16.0140

Lipowski, M., \& Angowski, M. (2017). Are phones still used as a distribution channel of services in the age of the internet? An empirical study. Proceedings of the 30th International Business Information Management Association Conference, IBIMA 2017 - Vision 2020: sustainable economic development, innovation management, and global growth, 2017 - January (February 2018) (pp. 4143-4151).

Liu, C. W., Lo, S. K., Hsieh, A. Y., \& Hwang, Y. (2018). Effects of banner Ad shape and the schema creating a process on consumer internet browsing behavior. Computers in Human Behavior, 86, 9-17. https://doi.org/10.1016/j.chb.2018.04.034

Lu, Q. S., Pattnaik, C., Xiao, J., \& Voola, R. (2018). Cross-national variation in consumers' retail channel selection in a multichannel environment: evidence from Asia-Pacific countries. Journal of Business Research, 86, 321-332. https://doi.org/10.1016/j.jbusres.2017.09.027

Marino V., \& Lo Presti L. (2018). Engagement, satisfaction and customer behavior-based CRM performance: An empirical study of mobile instant messaging, Journal of Service Theory and Practice, 28(5), 682-707. https://doi.org/10.1108/JSTP-11-2017-0222

Mihajlović, I. Krželj, Z., \& Milić, I. (2014). Study of the Impact of ICT on New trends in consumer behaviour in tourism when planning trips. Mathematics and Computers in Contemporary Science, 144-154. Retrieved from http://bit.ly/16MQrMA

Mihajlović, I. (2014). ICT and new trends in consumer behavior - new experiential knowledge, opportunities or challenges for intermediaries. Journal of Marketing Management, 2(1), 43-64.

Nieves-Rodriguez, E., Perez-Rivera, M. M., Longobardi, T., \& Davis-Pellot, J. A. (2017). Culture and gender's role in apparel purchasing patterns. Journal of Fashion Marketing and Management, 21(1), 16-32. https://doi.org/10.1108/JFMM-04-2016-0032

Ooi, K. B., Sim, J. J., Yew, K. T., \& Lin, B. (2011). Exploring factors influencing consumers' behavioral intention to adopt broadband in Malaysia. Computers in Human Behavior, 27(3), 1168-1178. https://doi.org/10.1016/j.chb.2010.12.011

Park, J., \& Kim, R. B. (2018). A new approach to segmenting multichannel shoppers in Korea and the. Journal of Retailing and Consumer Services, 45(February), 163-178. https://doi.org/10.1016/j.jretconser.2018.09.007

Pihkola, H., Hongisto, M., Apilo, O., \& Lasanen, M. (2018). Evaluating the energy consumption of mobile data transfer-from technology development to consumer behavior and life cycle thinking. Sustainability, 10(7), 1-16. https://doi.org/10.3390/su10072494

PostNord. (2018). E-commerce in Europe 2018: consumers' buying behavior increasingly global. PostNord, 58.

Rahman, M. A., Islam, M. A., Esha, B. H., Sultana, N., \& Chakravorty, S. (2018). Consumer buying behavior towards online shopping: An empirical study on Dhaka city, Bangladesh, Cogent Business and Management, 5(1), 1-22. https://doi.org/10.1080/23311975.2018.1514940

Rajh, E., Budak, J., \& Anić, I.-D. (2016). Hofstede's culture value survey in Croatia: examining regional differences. Drustvena Istrazivanja, 25(3), 309-327. https://doi.org/10.5559/di.25.3.02

Raudeliuniene, J., Davidavičiene, V., Tvaronavičiene, M., \& Jonuška, L. (2018). Evaluation of advertising campaigns on social media networks. Sustainability, 10(4), 1-14. https://doi.org/10.3390/su10040973

Robertson, A. W. (2015). What are ICTs? Management of Science.

Saarijärvi, H., Joensuu, J., Rintamaki, T., \& Yrjölä, M. (2018). One person's trash is another person' s treasure. International Journal of Retail \& Distribution Management, 46(11/12), 1092-1107. https://doi.org/10.1108/IJRDM-04-2017-0091

Saprikis, V. (2015). An empirical investigation of internet users' perceptions towards national and international e-shops, International Journal of E-Adoption, 7(2), 45-59. https://doi.org/10.4018/IJEA.2015070104

Saprikis, V., Markos, A., \& Zarmpou, T. (2018). Mobile shopping consumers' behavior. An Exploratory Study and Review, 13(1). https://doi.org/10.4067/S0718-18762018000100105

Scherer, J. O., Kloeckner, A. P., Ribeiro, J. L. D., Pezzotta, G., \& Pirola, F. (2016). Product-Service System (PSS) design: using design thinking and business analytics to improve PSS design. Procedia CIRP, 47, 341-346. https://doi.org/10.1016/j.procir.2016.03.062

Shop world. (2017). An overview of the Asian eCommerce opportunity. Retrieved from https://www.eshopworld.com/blog/ asianecommerce/

Stevens, G., Bossauer, P., Neifer, T., \& Hanschke, S. (2018). Using shopping data to design sustainable consumer apps. 5th IFIP Conference on Sustainable Internet and ICT for Sustainability, SustainIT 2017, (December), 1-3. https://doi.org/10.23919/SustainIT.2017.8379810

Su, N., Min, H., Chen, M. H., \& Swanger, N. (2018). Cultural characteristics and tourist shopping spending. Journal of Hospitality and Tourism Research, 42(8), 1210-1231. https://doi.org/10.1177/1096348017731131

Sukrat, S., Mahatanankoon, P., \& Papasratorn, B. (2018). The driving forces of C2C social commerce in Thailand: a developing framework. KnE Social Sciences, 3(1), 108-118. https://doi.org/10.18502/kss.v3i1.1400

Vasic, N., Kilibarda, M., \& Kaurin, T. (2019). The influence of online shopping determinants on customer satisfaction in the Serbian Market. Journal of theoretical and applied electronic commerce research, 14(2), 70-89. https://doi.org/10.4067/S071818762019000200107 
Vo, L. Van, Le, H. T. T., Vinh, D., Phung, T., Wang, Y.-H., \& Yang, F.-J. (2016). Customer satisfaction and corporate investment policies. Ssrn, 18(2), 202-223. https://doi.org/10.2139/ssrn.2832815

Wang, M., Cho, S., \& Denton, T. (2017). The impact of personalization and compatibility with past experience on e-banking usage. International Journal of Bank Marketing, 35(1), 45-55. https://doi.org/10.1108/IJBM-04-2015-0046

Xiang, Z., Magnini, V. P., \& Fesenmaier, D. R. (2015). Information technology and consumer behavior in travel and tourism: Insights from travel planning using the internet. Journal of Retailing and Consumer Services, 22, 244-249. https://doi.org/10.1016/j.jretconser.2014.08.005

Xiang, Z., Wang, D., O'Leary, J. T., \& Fesenmaier, D. R. (2015). Adapting to the internet: trends in travelers' use of the web for trip planning. Journal of Travel Research, 54(4), 511-527. https://doi.org/10.1177/0047287514522883

Xie, G., \& Paik, Y. (2018). Cultural differences in creativity and innovation: are Asian employees truly less creative than western employees? Asia Pacific Business Review, 25(1), 123-147.

Yuan, H., Xu, W., Li, Q., \& Lau, R. (2018). Topic sentiment mining for sales performance prediction in e-commerce. Annals of Operations Research, 270(1), 553-576. https://doi.org/10.1007/s10479-017-2421-7

Zhang, Y., Weng, Q., \& Zhu, N. (2018). The relationships between electronic banking adoption and its antecedents: A meta-analytic study of the role of national culture. International Journal of Information Management, 40(January), 76-87. https://doi.org/10.1016/j.ijinfomgt.2018.01.015 